\title{
Let the chips fall where they may
}

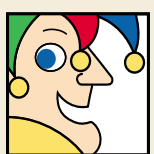

Tom Jacobs, of the Internet site Motley Fool (http://www.fool. $\mathrm{com} /$ ), provides his angle on biotechnology investments. Read on and become "Foolishly" informed*. He can be contacted about biotechnology and investing at TomJ@ Fool.com. Jacobs cannot give individual investment advice but welcomes any. He owns shares of Harvard Biosciences. The Motley Fool maintains an online real-money portfolio that had a short position in Affymetrix for four months in 2001

By the end of 2000, investors knew that the DNA microarray market was no mere speculation, because Motorola (Schaumberg, IL; NYSE:MOT), Corning (New York; NYSE:GLW) and Agilent (Palo Alto, CA)three advanced materials powerhouses with billions (pronounced beelyuns) in annual sales - all made large investments in the technology. No way were they allowing upstart firms like Affymetrix (Santa Clara, CA), Incyte Genomics (Palo Alto, CA; Nasdaq:INCY), or Hyseq (Sunnyvale, CA) to claim a projected $\$ 2$ billion market unchallenged.

How fast things change in two years. Corning's telecommunications business entered a depression. As a result, it cut costs and biochips. Later last year, Motorola's pain led it to sell its non-core microarray business to life sciences Amersham (Chalfont St. Giles, UK; NYSE:AHM; LSE:AHM) for a mere $\$ 20$ million. The mighty had fallen, but so had some of the small fry, who burned through cash while sources of new capital dried up. Incyte Genomics, too, exited the field.

So is there anything attractive here for investors?

\section{Where are they now?}

Today, investors will find 16 DNA microarray companies that are publicly traded, 10 of which trade in the United States subject to US accounting and regulatory rules. (I'm not

* Nature Biotechnology does not guarantee the veracity, reliability, or completeness of any information provided on this page; it is not responsible for any errors or omissions or for any results obtained from the use of such information; it will not be liable for any loss, damage, or investment decision arising from a reader's reliance on the information provided. saying the US systems are better or worse, only that I know them best.)

Half the group is healthy, the other half gasping for air.

At one extreme is Hyseq, all but dead as of September 30, which in November pulled a cloned rabbit out of its hat when it announced a merger with Variagenics, which had about 2.5 years of cash left itself (Nat. Biotechnol. 21, 5; 2003). The parties reasonably estimate that if the deal closes, the new company's cash will feed them until December 2004. Then what? Stay away.

Nanogen (San Diego, CA) is in hot water, too. Absent a change in its flat to declining revenues, its cash stash will last 1.5 to 2 years at current burn rates. As for CombiMatrix, in its last quarter before a restructuring with 48\% owner Acacia Research (Pleasanton, CA; Nasdaq:ACRI), it had about three quarters of cash left. Not good.

Genomic Solutions (Ann Arbor, MI; Nasdaq:GNSL) has also been on the critical list. In the first six months of its 2002 fiscal year, it had \$12 million in cash remaining and had burned through $\$ 7$ million. Luckily, knight-in-cash-laden armor Harvard Bioscience (Holliston, MA) agreed to buy the company for $\$ 26$ million in cash and stock-a mere $\$ 16.5$ million more than the company's cash minus debt on its credit line. Because Harvard Bioscience was free-cash-flow positive, Genomic Solutions shareholders were happy. Beats bankruptcy.

\section{"A"-biased market}

This leaves six companies. Agilent, a communications, electronics, and life sciences spinoff of Hewlett-Packard (Palo Alto, CA; Nasdaq:HPQ), had a lousy year through September 30. It hasn't produced profits since 2001 and managed to eke out free cash flow (FCF) only in one quarter of the last eight (for an explanation of enterprise value and FCF, see Nat. Biotechnol., 20, 219; 2002). But with cash over $60 \%$ greater than longterm debt and steadily improving cash management, Agilent is not going away.

Shares of comfortably cash-generating Apogent (Portsmouth, NH) and Invitrogen (Carlsbad, CA) sell for enterprise value to FCF multiples in the low 20s. This is high for Apogent, whose growth in FCF has stalled in the past year, and fair for Invitrogen, which has produced seven straight quarters of solid FCF, despite flat revenues.

PerkinElmer (Boston, MA) is overpriced relative to its FCF generation and is weighed

\begin{tabular}{ll}
\multicolumn{2}{l}{ Table 1. US public companies with } \\
significant DNA microarray businesses \\
Company & Ticker \\
\hline Affymetrix & (Nasdaq:AFFX) \\
$\begin{array}{l}\text { Agilent } \\
\text { Apogent }\end{array}$ & (NYSE:A) \\
$\begin{array}{l}\text { Becton Dickinson } \\
\text { (Clontech) }\end{array}$ & (NYSE:AOT) \\
$\begin{array}{l}\text { CombiMatrix } \\
\text { Harvard Bioscience } \\
\text { (Genomic Solutions) }\end{array}$ & (Nasdaq:CBMX) \\
$\begin{array}{c}\text { Hyseq (N-mer joint } \\
\text { venture with }\end{array}$ & (Nasdaq:HYSQ) \\
$\begin{array}{c}\text { Affymetrix) } \\
\text { Invitrogen (ResGen) }\end{array}$ & \\
$\begin{array}{l}\text { Nanogen } \\
\text { PerkinEImer }\end{array}$ & (Nasdaq:IVGN) \\
\end{tabular}

down by total debt over four times its cash. Becton Dickinson (Palo Alto, CA) has superb financials and is selling at a very reasonable valuation, but it's not an investment in as broad a DNA microarray product offering as others.

\section{Iffy about Affy?}

For more aggressive investors, that leaves us with Affymetrix, actually generating positive FCF for the two quarters through Sept. 30 (even subtracting the substantial cash benefit Affymetrix earns from issuing stock options). But a couple of cents of FCF a share doesn't yet support an enterprise value of $\$ 1.4$ billion. If and when the market catches on, the shares could drop substantially. Red flag: \$375 million in debt due in 2006 and 2007?

Four companies may be the most likely to survive because they produce products across the spectrum (Nat. Biotechnol. 20, 8; 2002)-arrayers, low- and high-density chips, hardware, and software. Amersham (owns Amersham Biosciences), Harvard Bioscience (owns Genomic Solutions), Affymetrix, and PerkinElmer. If you are comfortable with UK financials and can make sense of the company's myriad acquisitions, Amersham is intriguing. Aggressive investors may keep the second and third on their radar. PerkinElmer is improving its cash management, but has a long way to go before I'd look more closely.

If Invitrogen and Apogent maintain and increase FCF, they may represent good values on any price declines. But the best poised for steady long-term growth is Becton Dickinson. Definitely worth a closer look.

Until next month, stay Foolish! 